\title{
Sequence stratigraphic analysis of the Otu Field, onshore Niger Delta, using 3D seismic data and borehole logs
}

\author{
Oluseun Adetola SANUADE ${ }^{1, *}$ and SanLinn I KAKA ${ }^{1}$ \\ 1 King Fahd University of Petroleum and Minerals, Department of Geosciences, Dhahran 31261, Saudi Arabia
}

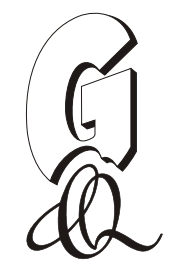

Sanuade, O.A., Kaka, S. I, 2017. Sequence stratigraphic analysis of the Otu Field, onshore Niger Delta, using 3D seismic data and borehole logs. Geological Quarterly, 61 (1): 106-123, doi: 10.7306/gq.1318

\begin{abstract}
3D seismic data and wireline logs from thirteen boreholes were used to establish a sequence stratigraphic analysis of Miocene depositional systems of the Otu Field in the onshore area of the Niger Delta. The subsurface facies of the field revealed three sequences that are bounded by four sequence boundaries (SBs) which are interpreted as erosional unconformities with three maximum flooding surfaces (MFSs). Sequences delineated are composed of lowstand systems tracts (LST), falling stage systems tracts (FSST), transgressive systems tracts (TST) and highstand systems tracts (HST) revealing depositional systems deposited during different phases of base level changes. Deposits identified within the LSTs are fluvial channel sands while TSTs capped the LST facies. HSTs are composed of coarsening and shallowing upwards intervals including deltaic fluvial sands. The sequences were deposited in transitional to shallow marine environments. A seismic geomorphological study carried out on all the SBs and MFS 3 shows a relationship between depositional environments, channel type and direction of palaeo-flow in relation to faults. The reservoirs of the LST and HST and seals from marine shale of the TST and HST could form stratigraphic traps for hydrocarbon accumulation in the Otu Field. This study has integrated 3D seismic and borehole log data to develop a sequence stratigraphic framework that would be a profitable means to guide hydrocarbon exploration and production strategies.
\end{abstract}

Key words: subsurface facies, stratigraphic trap, seismic geomorphology, sequence boundaries, channel.

\section{INTRODUCTION}

Sequence stratigraphy provides the basis for the chronostratigraphic correlation of strata and a valuable exploration and reservoir development tool for the petroleum industry. An approach of sequence stratigraphy in association with knowledge of depositional environments as well as appreciation of the importance of accommodation space and sediment supply can aid in the reconstruction of palaeogeography and help prediction of temporal and spatial relationships between source, reservoir and seal facies (Catuneanu et al., 2011). Sequence stratigraphy is used to locate stratigraphic prospects and predict reservoir and seal quality on structural prospects. This approach was applied to the Otu Field in the Niger Delta.

The Cenozoic Niger Delta is a clastic wedge that is $12 \mathrm{~km}$ in thickness with an area of $75,000 \mathrm{~km}^{2}$ between southern Nigeria and the Gulf of Guinea (Evamy et al., 1978). The deposits in the Niger Delta are known to be subdivided into three lithostratigraphic units, these being the Akata Formation, Agbada Formation, and Benin Formation (Short and Stauble, 1967). The three formations in the Niger Delta become progressively

\footnotetext{
* Corresponding author, e-mail: sheunsky@gmail.com Received: August 29, 2015; accepted: June 24, 2016; first published online: October, 17, 2016
}

younger basinward, showing long-term progradation of the depositional environments of the Niger Delta into the passive margin of the Atlantic Ocean. The stratigraphy of the Niger Delta is complex as a result of syndepositional slumping of the clastic wedge due to movement of shale of the Akata Formation by the influence of the load of the Agbada and Benin formations, which are prograding deltaic and fluvial accumulations, respectively. A network of large-scale, listric normal faults dipping towards the basin formed as a result of diapiric upward mobility of the underlying shales. Blocks down-dropped across these faults loaded with growth strata, changed the local slopes of deposition, resulting in complex pathways of sediment transport into the basin (Evamy et al., 1978). This has made field evaluation in the basin difficult due to problems associated with imaging of the subsurface in the Niger Delta. For the purpose of field evaluation, it is important to understand detailed relationships between the fault system in the area and the stratigraphic component of the basin. It has been shown that when 3D seismic data is integrated with borehole log data, it provides a powerful tool to determine the seismic stratigraphic and structural framework of a basin (Nton and Adesina, 2009; Futalan et al., 2012; Oyedele et al., 2013; Fagbenro and Woma, 2013; Amigun et al., 2014; Onayemi and Oladele, 2014). Hence, this study was carried out with the objectives of establishing the tectono-stratigraphic evolution of the Otu Field in the Niger Delta, identifying different facies and their depositional environment(s) and establishing a sequence stratigraphic framework within the study area. 


\section{LOCATION OF STUDY AREA AND GEOLOGY}

The Otu Field is located onshore in the western part of the Niger Delta and straddles the central swamp and coastal swamp depobelt of the Niger Delta (Fig. 1). The Cenozoic Niger Delta is situated in the Gulf of Guinea, in West Africa. It represents the southern margin of a triple junction rift system that triggered the separation of the African continent from the South American continent during the Jurassic through the Early Cretaceous (Doust and Omatsola, 1990). Rifting started around Late Jurassic time and continued to the middle Cretaceous
(Lehner and De Ruiter, 1977). During the Late Cretaceous, rifting reduced. At the end of rifting, gravity tectonism occurred as the main process of deformation. Internal deformation was induced by the mobility of shale.

Short and Stauble (1967) subdivided the Niger Delta into three lithostratigraphic units, ranging in age from Paleocene to Recent. They include the Akata, Agbada and Benin formations (Fig. 2). The Akata Formation is marine in origin and consists of thick shale sequences. The Akata Formation is situated at the base of the Niger Delta and consists of prodelta, hemipelagic, and pelagic shales that were deposited in marine environments. The formation is Late Paleocene to Early Pliocene in age. The Akata Formation is characterized by high plasticity and over-
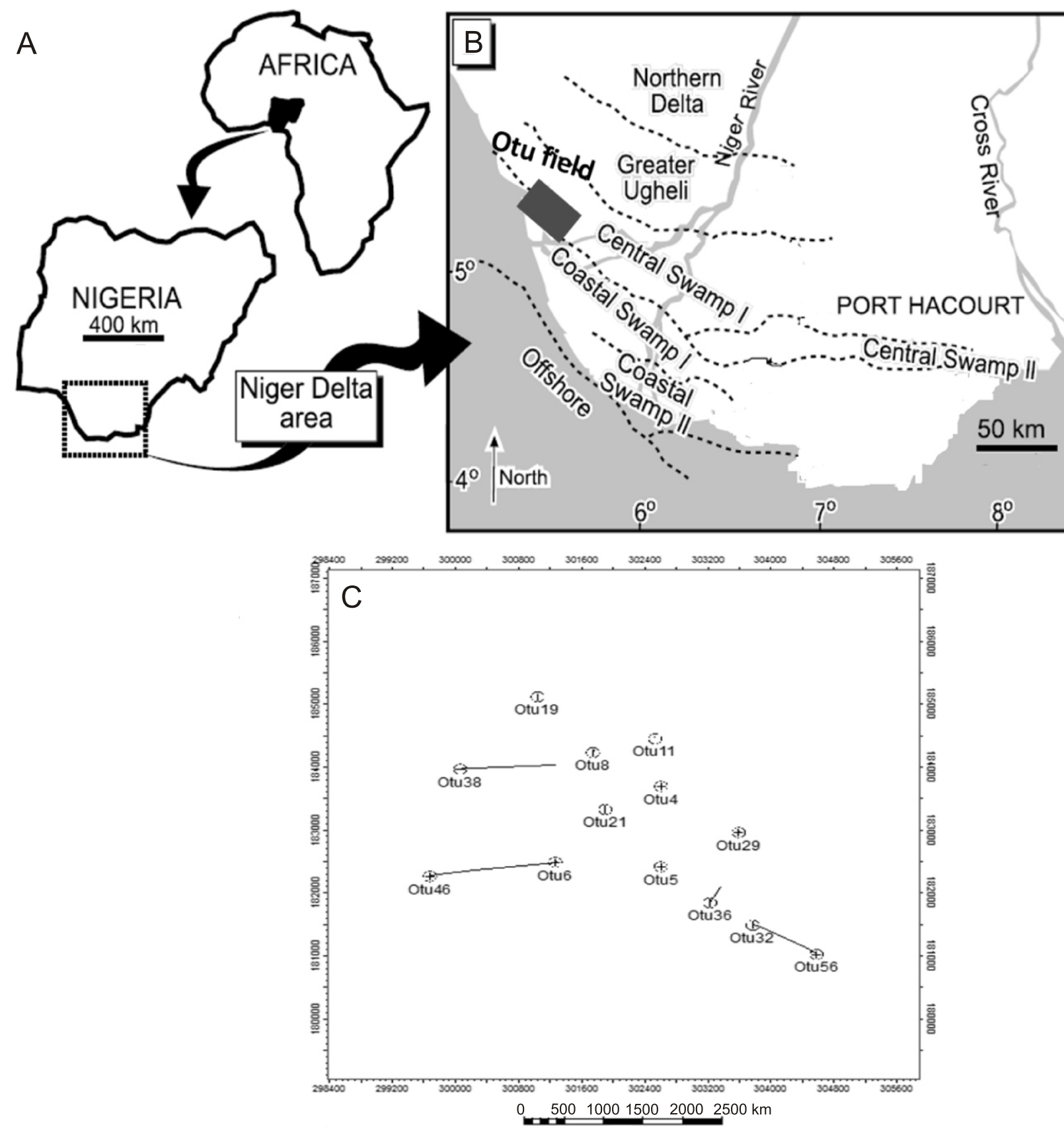

Fig. 1. Location map of the study area

A - position of Nigeria in Africa and the Niger Delta Basin; B - the Otu Field location map; C - Otu Field borehole locations; A and B were modified after Doust and Omatsola (1990) 
pressure, especially at depth. All major faults and counter-regional faults merge into a plane (or detachment surface) in the lower part of the Akata Formation. The Agbada Formation consists of a paralic sequence of interbedded sands and shales. The sandstones were deposited in prograding transitional or coastal environments comprised of fluvio-deltaic and barrier islands of the delta front, lagoon, brackish-water bays, beaches, and the shoreface. Shales are prodelta to hemipelagic in origin. The Agbada Formation is Eocene to Pleistocene in age and about $3,700 \mathrm{~m}$ thick. The Benin Formation consists of continental sandstones that were deposited on a delta plain as point bars by meandering streams or as channel-fills with natural levees (Doust and Omatsola, 1990). The massive freshwater bearing Benin Formation occurs widely across the Niger Delta, with thicknesses ranging between 300 and $3,000 \mathrm{~m}$.

The main source rock of the Niger Delta petroleum system is the Akata Formation (Evamy et al., 1978; Ejedawe, 1986; Nwachukwu and Chukwura, 1986; Bustin, 1988). The Agbada Formation in the Niger Delta serves as the hydrocarbon reservoir. It is described as intercalations of sand and shale (Doust and Omatsola, 1990). Growth faults that detach on the Akata Formation provide the pathways through which the porous and

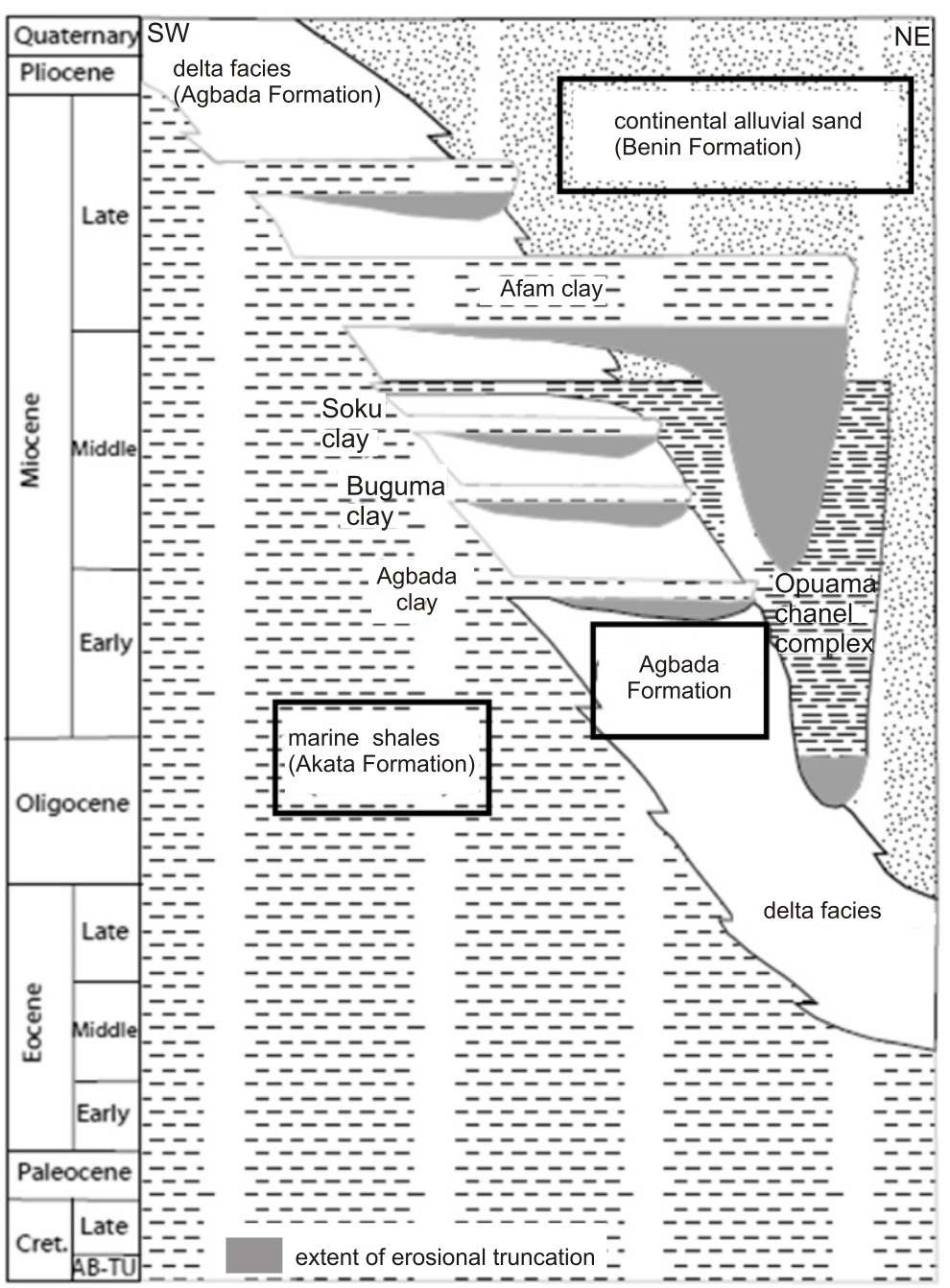

Fig. 2. Stratigraphic column depicting three formations of the Niger Delta (modified from Doust and Omatsola, 1990)

Marine shales of the Akata Formation are the source rock, while the Agbada Formation is the reservoir rock in the basin permeable sandstones of the Agbada Formation are interconnected. The shales of the Agbada Formation serve as the local seal, in combination with the appropriate fault framework.

The Benin Formation (continental sands) is believed play a subordinate role in the generation and the preservation of hydrocarbons in the Niger Delta (Doust and Omatsola, 1990). The Benin Formation is, however, thick enough (300-3,000 m) to serve as a significant overburden rock.

Corredor et al. (2005) subdivided the delta into five structural zones (Fig. 3) based on seismic interpretation. The zones comprise: an extensional province; a zone of mud diapirs; the inner fold and thrust belt; a transitional detachment fold zone; and the outer fold and thrust belts. The Otu Field is situated within the extensional province defined by basin-dipping listric faults.

\section{DATA AND METHODOLOGY}

\section{DATA SET FOR THE STUDY}

The data used for this study include a 3D seismic cube, 13 wireline logs, check shot and deviation survey data. The 3D seismic amplitude data covers an area of about $421 \mathrm{~km}^{2}$ of the onshore area of the Niger Delta. The bin spacing of the seismic data is 25 by $25 \mathrm{~m}$ and these are available in milliseconds two-way travel time (ms TWTT) with a maximum value of $3000 \mathrm{~ms}$ Suites of wireline logs include gamma ray (GR) logs resistivity logs, neutron logs, density logs and spontaneous potential logs.

\section{METHODOLOGY}

Identification of facies and depositional environments. Gamma ray (GR) log patterns were used for the identification of facies and their depositional environments (Beka and Oti, 1995). A "blocky" log pattern was interpreted to represent uniform deposition that was peculiar to the channelized region and typical of fluvial channel deposits. A pattern showing coarsening-upwards units (a progradational pattern) was interpreted to be a feature of a deltaic fluvial environment (channel point bars). A "serrated" (aggradational log pattern) with uniform bandwidth shows limited coastline variability and was interpreted to be typical of a floodplain environment. A "bell-shaped" GR log pattern (upwards fining, retrogradational log pattern) was interpreted to represent overbank deposits.

\section{BOREHOLE LOG ANALYSIS}

Chronostratigraphy. Chronostratigraphic correlation of time-significant surfaces was performed using the borehole logs available for the study. This was carried out by the borehole log sequence stratigraphic interpretation of individual boreholes using the stacking pattern such as progradation, retrogradation and aggradation which aided the delineation of the lateral continuity of facies within the systems tract. The depositional (IV) model of Hunt and Tucker (1992, 1995) and Helland-Hansen and Gjelberg (1994) (Fig. 4) was employed for the subsurface facies within the Agbada Formation. 


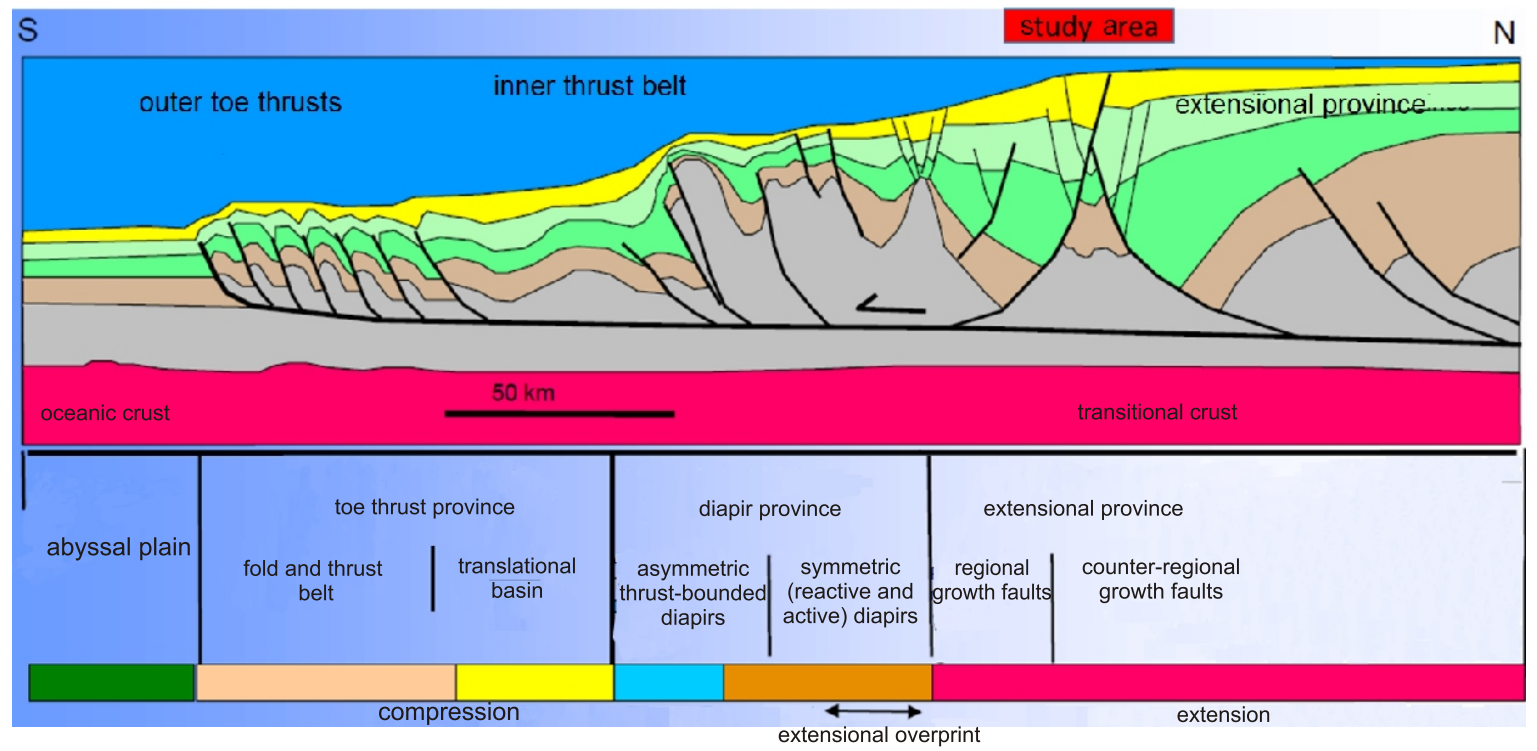

Fig. 3. Structural styles of the deep-water Niger Delta

The three provinces in the Niger Delta are the toe thrust, diapir and extensional province; the Otu Field falls within the extensional province (modified from Corredor et al., 2005); the green colour represents the abyssal plain, the brown colour is the fold and thrust belt, while yellow indicates the transitional basin; the asymmetrical thrust-bounded diapirs are represented by a blue colour, while a orange colour represents the symmetrical diapirs; the extensional province is coloured pink

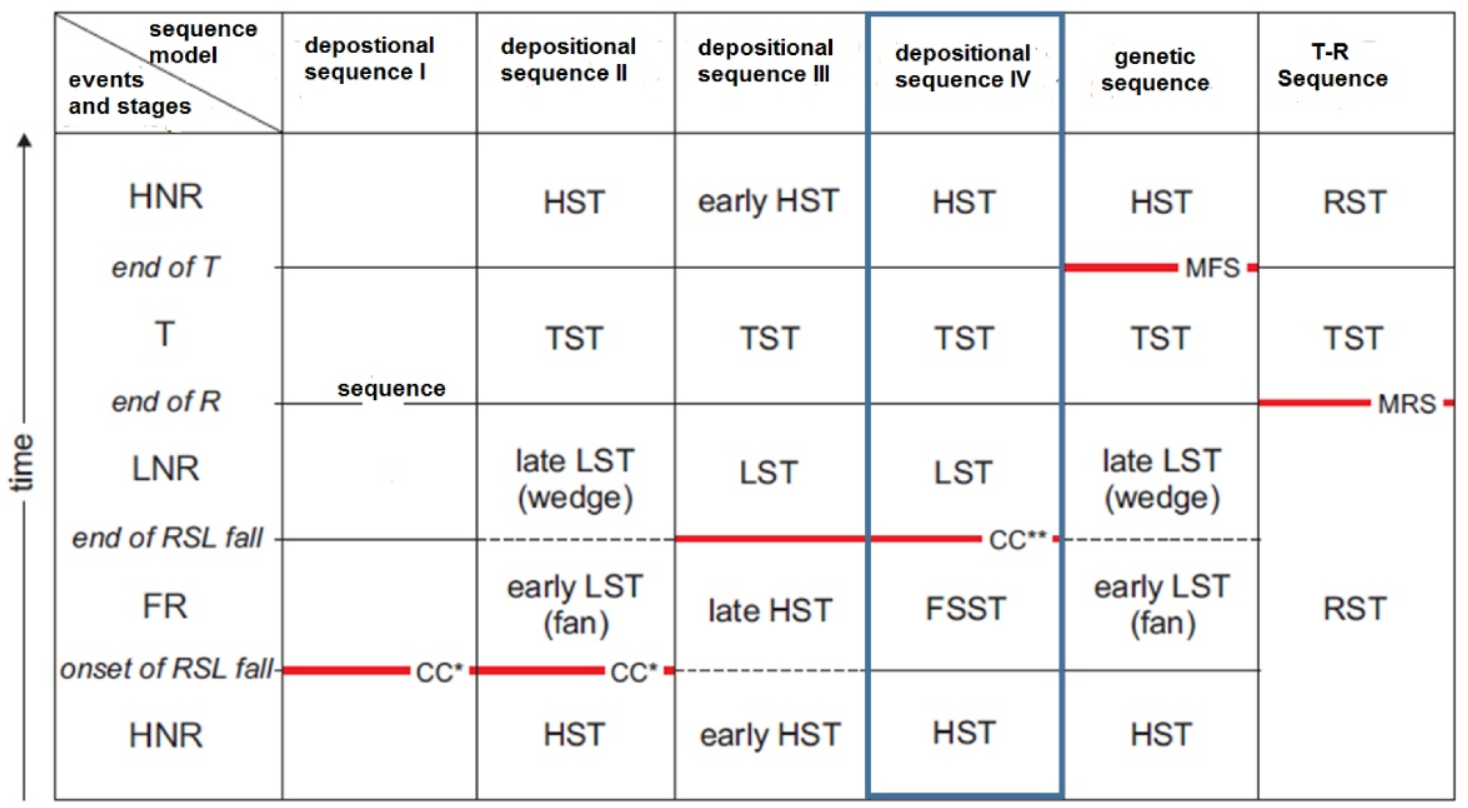
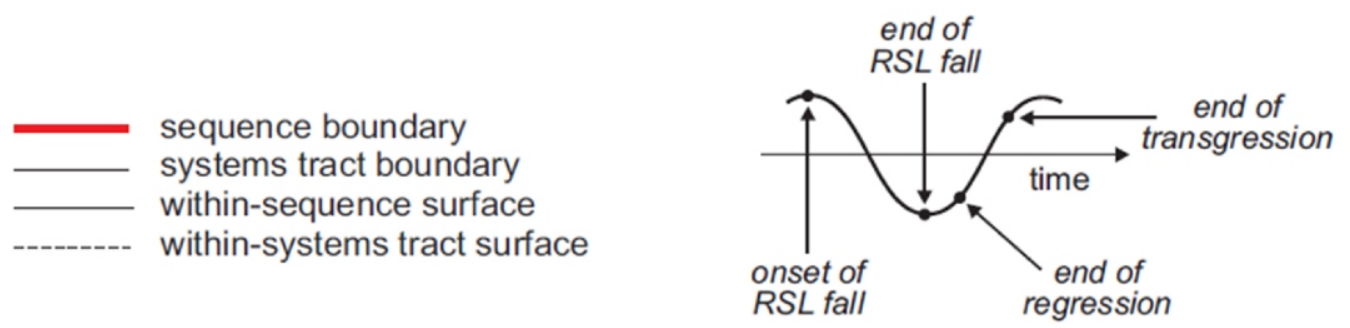

Fig. 4. Nomenclature of systems tracts, and timing of sequence boundaries for the various sequence stratigraphic approaches (modified from Catuneanu et al., 2011)

$\mathrm{CC}^{*}$ - correlative conformity in the sense of Posamentier and Allen (1999); CC ${ }^{* *}$ - correlative conformity in the sense of Hunt and Tucker (1992); FR - forced regression; FSST - falling-stage systems tract; HNR - highstand normal regression; HST - highstand systems tract; LNR - lowstand normal regression; LST - lowstand systems tract; MFS - maximum flooding surface; MRS - maximum regressive surface; $\mathrm{R}$ - regression; RSL - relative sea level; RST - regressive systems tract; $\mathrm{T}$ - transgression; $\mathrm{T}-\mathrm{R}$ - transgressive-regressive; TST transgressive systems tract 
The chart in Figure 5 was used for the interpretation of borehole log sequence stratigraphy and depositional environments.

Lithostratigraphy. The hydrocarbon-bearing sands were identified and their correlation allowed for the establishment of the lateral continuity of the subsurface reservoir facies penetrated by the boreholes.

\section{SEISMIC ANALYSIS}

Seismic stratigraphy. The identification of stratal terminations aided the identification of time-significant surfaces. Stratal terminations are the geometric relationship between strata and the stratigraphic surface against which they terminate. The main types of stratal termination are described as truncations, toplaps, onlaps, downlaps, and offlaps (Catuneanu, 2002). They have been integrated into sequence stratigraphy so as to describe the stacking patterns of stratal units and to give diagnostic features for the recognition of the various surfaces and systems tracts (Van Wagoner et al., 1990; Christie-Blick, 1991).

Seismic geomorphology. Seismic geomorphology may be defined as the application of analytical techniques pertaining to the study of landforms and to the analysis of ancient, buried geomorphological surfaces as imaged by $3 \mathrm{D}$ seismic data.

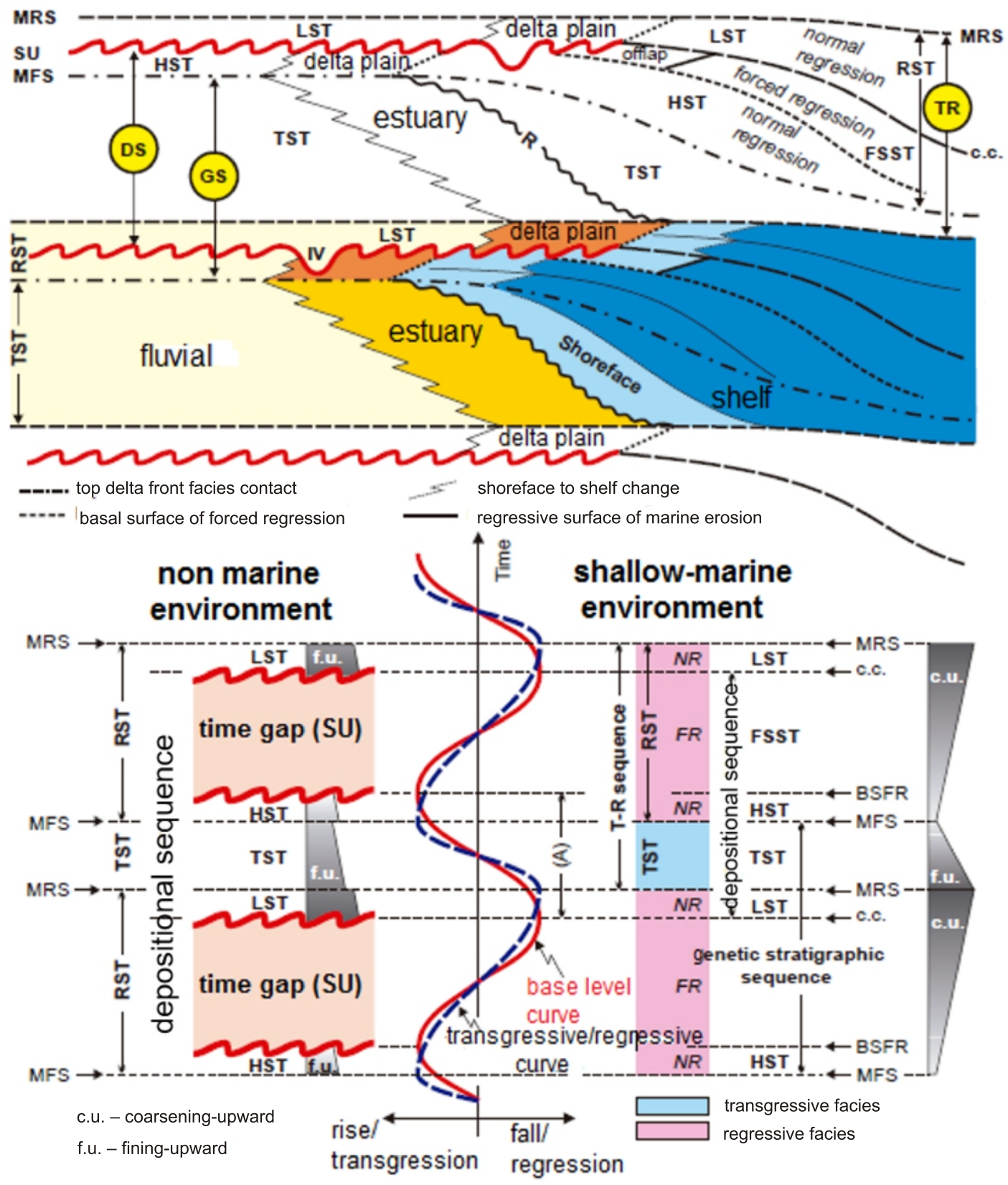

Fig. 5. Sequences, systems tracts, and stratigraphic surfaces defined in relation to the base-level and to the transgressive-regressive curves (after Catuneanu et al., 2011)

BSFR - basal surface of forced regression, c.c. - correlative conformity, DS - depositional sequence, GS - genetic stratigraphic sequence, NR - normal regression, TR - transgressive-regressive sequence, SU - subaerial unconformity, R - transgressive wave-ravinement surface, (A) - positive accommodation (base-level rise); for other explanations see Figure 4 
Seismic geomorphology, when used in conjunction with seismic stratigraphy, represents the state-of-the-art approach to extracting stratigraphic insights from 3D seismic data (Posamentier et al., 2007).

\section{DATA ANALYSIS AND INTERPRETATION}

\section{FACIES ANALYSIS}

Three facies and their depositional environments were delineated in the Otu Field using the gamma ray (GR) log motifs. With the use of standard interpretations for the Agbada Formation, successions of logs that gradually decrease in GR value and then rapidly increase are interpreted to be prograding delta deposits.

Log successions that abruptly decrease in GR value and have "blocky" or gradually increasing trends are interpreted to be fluvial channel deposits. "Serrated" high GR value intervals are known to be dominated by shales with different amounts of thin beds of sandstones and are interpreted to represent a fluvial floodplain (Fig. 6). GR having low and high values and are "bell-shaped" were interpreted as tidal channels.

Facies 1: shaly sandstone facies. This facies is made up of fine-grained sandstone with intercalations of shale. It is characterized by a blocky to slightly fining-up GR log pattern (Fig. 7A). This pattern is a common feature of a deltaic fluvial environment.

Facies 2: sandstone facies. This facies is composed of bodies of sand that are characterized by a stack of coarsening-up units in the GR log motif (Fig. 7B). This log pattern depicts uniform deposition and the facies are peculiar to a channelized region. This facies is interpreted to be fluvial channel deposits within the estuary. The presence of serration may indicate tidal influence.
Facies 3: mudrock facies. This facies is made up of units of shale having intercalations of thin shaly sandstone displaying a retrogradational parasequence pattern. It is characterized by serrated GR log character with uniform bandwidth indicating limited coastline variability (Fig. 7C). Based on these characteristics, it is interpreted to represent a fluvial floodplain.

The mudrock facies is the oldest in the area and forms the base of the sequence (Fig. 8). This facies is of marine origin (i.e., delta front environment). The shaly-sandstone facies succeeds the mudrock facies and constitutes the paralic sequence of the study area. The youngest facies is the sandstone facies, which is continental in origin. It was deposited in a delta plain environment and forms the top part of the sequence.

Stratigraphy of the Otu Field. The variations in stratigraphy of the Agbada Formation of the Otu Field reflect the regression of depositional environments within the Niger Delta Basin by changing broadly from fine-grained deposits in deeper boreholes directly above, underlying the shales of the Akata Formation (high GR log values), to progressively coarser-grained deposits in shallower boreholes below the overlying Benin Formation (lower GR log values).

Stratigraphic surfaces were correlated within the boreholes of the Otu Field along the strike and dip in the field (Fig. 8). Three sequences were identified and delineated. Sequence one is an incomplete sequence due to the depth at which logging terminated. Sequence two is a complete sequence with a lowstand prograding wedge (LPW) as its youngest systems tract and a falling stage systems tracts three (FSST-3) as the oldest systems tract. The FSST is sharp-based, suggestive of forced regression in the more distal portion of the shallow marine environment. Sequence boundary three (SB-3) marks the end of sequence two and the beginning of sequence three. Sequence three extends from the Agbada Formation to the Benin Formation in Otu Field. The maximum regressive surface three (MRS-3) marks the end of sequence three with MFS 3 (base of the Benin Formation) capping the underlying TST 3 sealing facies.

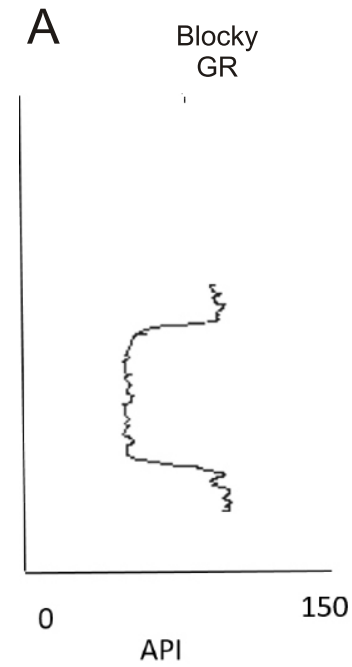

aggrading fluvial channe
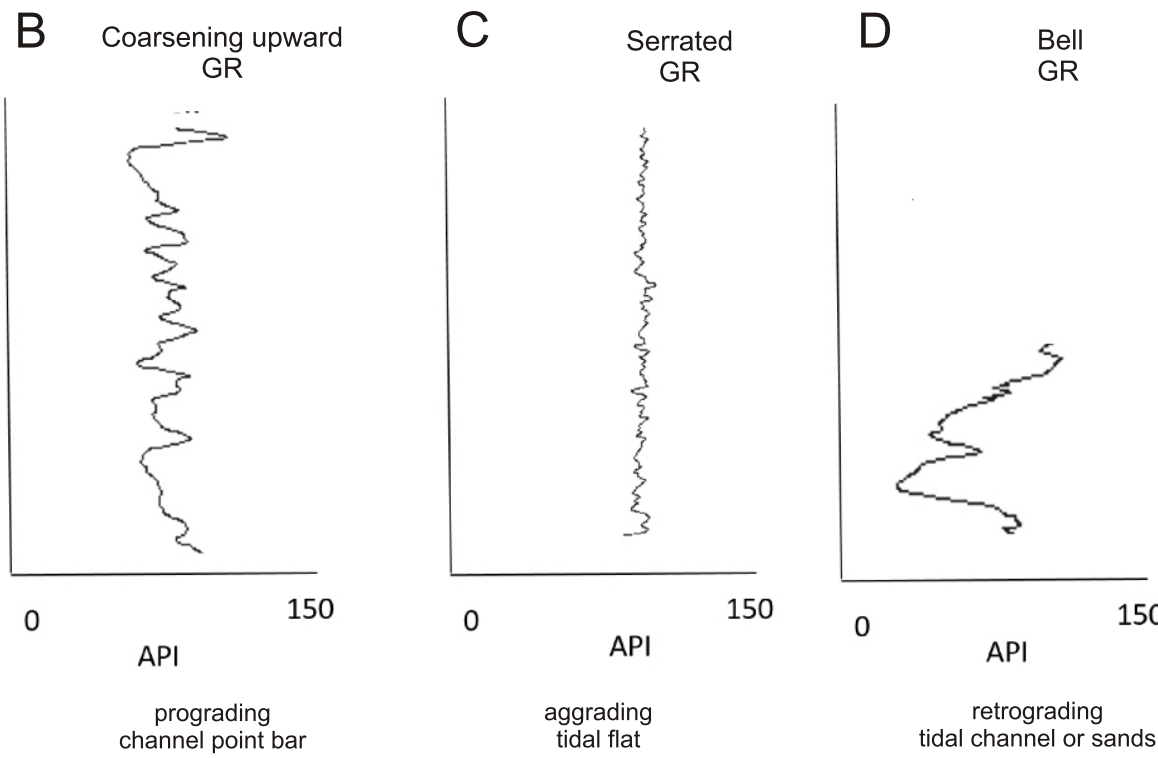

retrograding tidal channel or sands

Fig. 6. Types of borehole log patterns in the Otu Field

A - blocky log pattern; B - upwards coarsening, progradation log pattern; C - serrated, aggradational log pattern; D - bell-shaped, upward-fining, retrogradational log pattern 

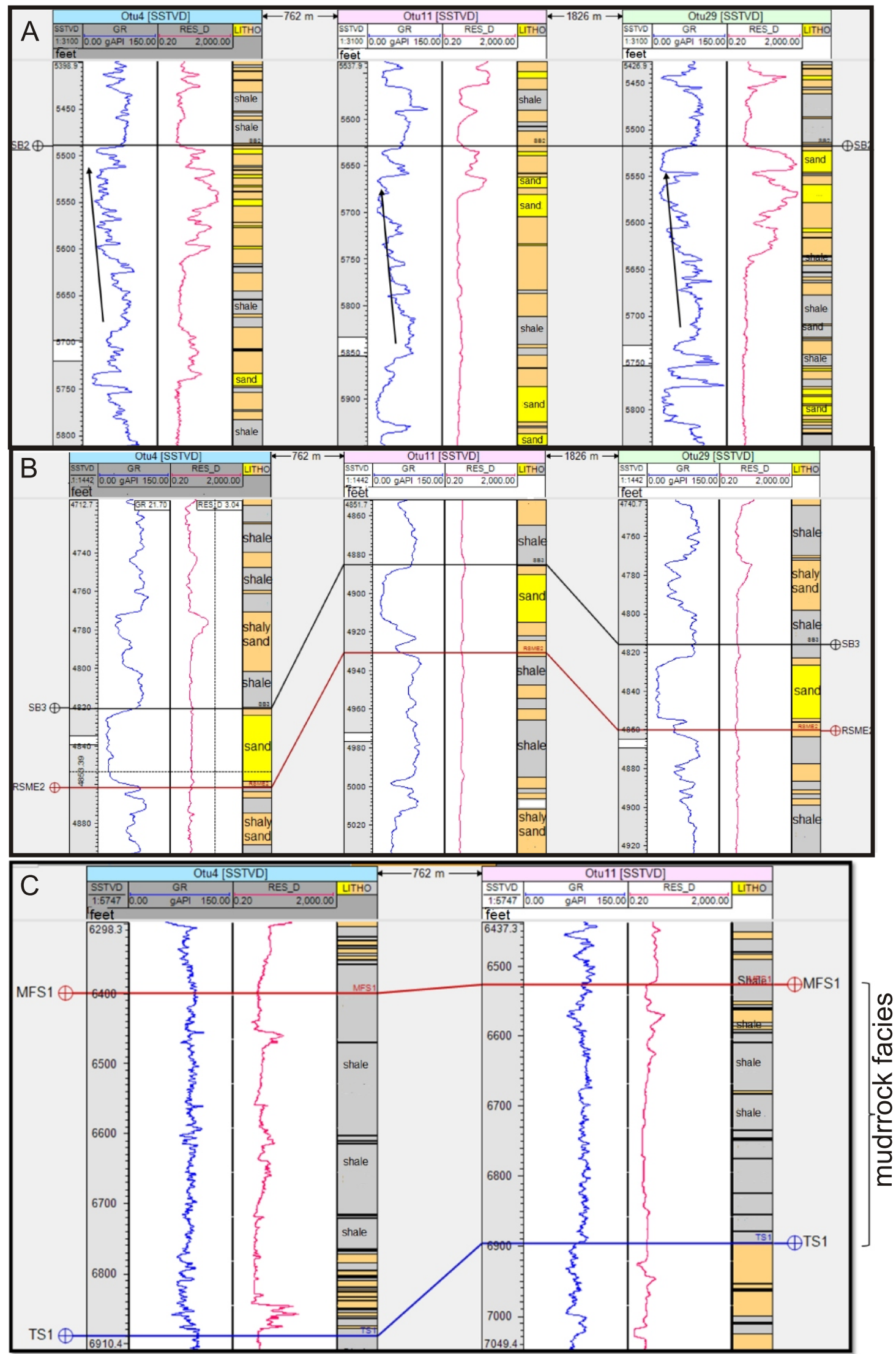

Fig. 7A - shaly sandstone facies represented by a blocky to slightly fining-up GR log pattern; SB means sequence boundary; B sandstone facies represented by a stack of coarsening-up units in the GR log pattern; SB means sequence boundary and RSME is regressive surface of marine erosion; $\mathrm{C}$ - mudrock facies represented by a serrated GR log pattern; MFS and TS are maximum flooding surface and transgressive surface respectively 


\section{LITHOSTRATIGRAPHIC CORRELATION} OF THE BOREHOLES

A lithostratigraphic correlation was carried out for the subsurface facies of the Agbada Formation penetrated by three boreholes in the field (Fig. 9). Fourteen sand reservoirs were identified and correlated. Sand $\mathrm{N}$ is the deepest correlated sand, the top of which was encountered at different depths in almost all the boreholes. Sand A is the shallowest hydrocarbon-bearing reservoir that was penetrated by all the boreholes at different depths.

\section{SEISMIC STRATIGRAPHY ANALYSIS}

The seismic stratigraphy analysis was carried out on the 3D seismic data (Fig. 10). The stratal terminations were used to infer the various shoreline shifts such as transgression and regression (both normal and forced regressions) and their respective diagnostic depositional trends such as progradation, retrogradation and aggradation. Having successfully integrated the borehole data to the seismic using checkshot data, consistency was established between the stratigraphic surfaces independently interpreted from both datasets (Vail, 1987).

The prevalence of incised valleys accompanied by seismic reflections truncating at the base of the channels serves as evidence for sequence boundaries in most cases. Fluvial down-cutting and the formation of incised valleys are typically formed during a major fall in sea level at the shoreline.

Sequence boundary one (SB-1) is the deepest sequence identified. This sequence has an interfluve sequence boundary SB-1 that shows a merging of SB-1 and TS 1 allowing LST 1 to be localized within the channel (Fig. 11). Sequence boundary two (SB-2) separates the underlying sequence one from the overlying sequence two. The underlying HST 1 is characterized by inclined beds, which are prograding clinoforms terminating at the base of SB-2 (Fig. 12). The shallow sequence three extends from the Agbada Formation into the Benin Formation. Sequence boundary three (SB-3) separates the underlying sequence two from the overlying sequence three. SB-3 bounds the base LST 3 . The overlying channel-fill within LST 3 has a complex geometry, which characterizes the channel-fill. In this case, TS 3 does not merge with SB-3. Therefore, the lowstand deposit within LST 3 should be widespread and not localized (Fig. 13).

Several channelized systems exist between the Benin and Agbada formations such as the Soku clay, Buguma clay, Agbada clay and Opuama channel complex (Fig. 2). Such channels are well-pronounced within the Otu Field as the channels extend all through the 3D seismic sections. Figure 14 reveals more perspectives of SB-3, which separates the underlying sequence two from the overlying sequence three. The channel is bounded at its base by SB- 3 which merges with TS 3 , MFS 3 and SB-3; hence, revealing the interfluve nature of SB-3. In some other areas, this channel is bounded at its base by MFS 3 . These variations show that the intensity of the erosional event that led to the down-cutting of the underlying TST 3 and MFS 3 is not the same all through. This therefore led to the presence of these systems tracts in some areas and their absence in some others.

The truncation of reflections below the channel is also found to be consistent with SB-4, independently identified from borehole logs. The channel associated with this event is within the continental Benin sands. Sequence boundary four (SB-4) separates the underlying sequence three from the overlying sequences (Fig. 15).

The relationship between systems tracts, reservoirs and their respective depositional environments are shown in Table 1.

\section{SEISMIC GEOMORPHOLOGY}

A seismic geomorphological approach was applied to the subsurface facies of the Agbada Formation. The patterns observed from the 3D seismic images are diagnostic of depositional environments. The study gives an indication of the internal and external architecture of the reservoirs, which furthers our understanding of the depositional processes that constructedthe various stratigraphic features.

The stratigraphically mapped horizons of SBs were auto-tracked and attributes such as spectral decomposition and similarity (coherency) were draped on the auto-tracked surfaces in order to enhance the identification and interpretation of the stratigraphic features.

Spectral decomposition outputs the amplitude at discrete frequencies. It resolves the seismic signal into its constituent frequencies, which enables interpreters to see phase and amplitude tuned to certain wavelengths. The amplitude component excels at quantifying the variability of thickness and detection of lateral discontinuities while the phase component reveals lateral discontinuities. For this study, it provides a powerful tool for "below resolution" seismic interpretation, estimation of sand thickness, and enhancement of channel structures. Coherency/similarity together with colour-blended spectral images help better illustrate geological information.

Sequence boundary four (SB-4) is the shallowest stratigraphic surface mapped within the Benin Formation with an overlying lowstand deposit LST 4. The direction of palaeoflow of the S-shaped meandering channel is NE-SW (Fig. 16). The channel is visible at the footwall of the E-W trending normal fault but was not observed $i$ the hanging wall area. However, sediment waves were observed in the hanging wall area. The channel disappears on interception with normal faults.

A relatively pronounced sinuous channel was observed in the northeastern part of the field. The direction of palaeoflow is NE-SW and perpendicular to the fault trace (Fig. 17). The strength of incision is perturbed by the faulting event causing the channel to be pronounced at the footwall of the normal fault. The individual channels observed on SB-2 and SB-3 are subtle and directed along the hanging wall of the fault, running parallel along the fault trace (Fig. 18).

\section{DEPOSITIONAL SEQUENCE ARCHITECTURE}

The depositional sequences within the Otu Field include three sequences that were mapped with their systems tracts as a result of the interplay of variation in sea level and accommodation rates.

The depositional systems in the Otu Field comprise LST, TST, FSST and HST. Sediments identified within the LST in the Otu Field consist mainly of fluvial channel sands. These sands are related to the erosion of canyons into slopes as well as inci- 


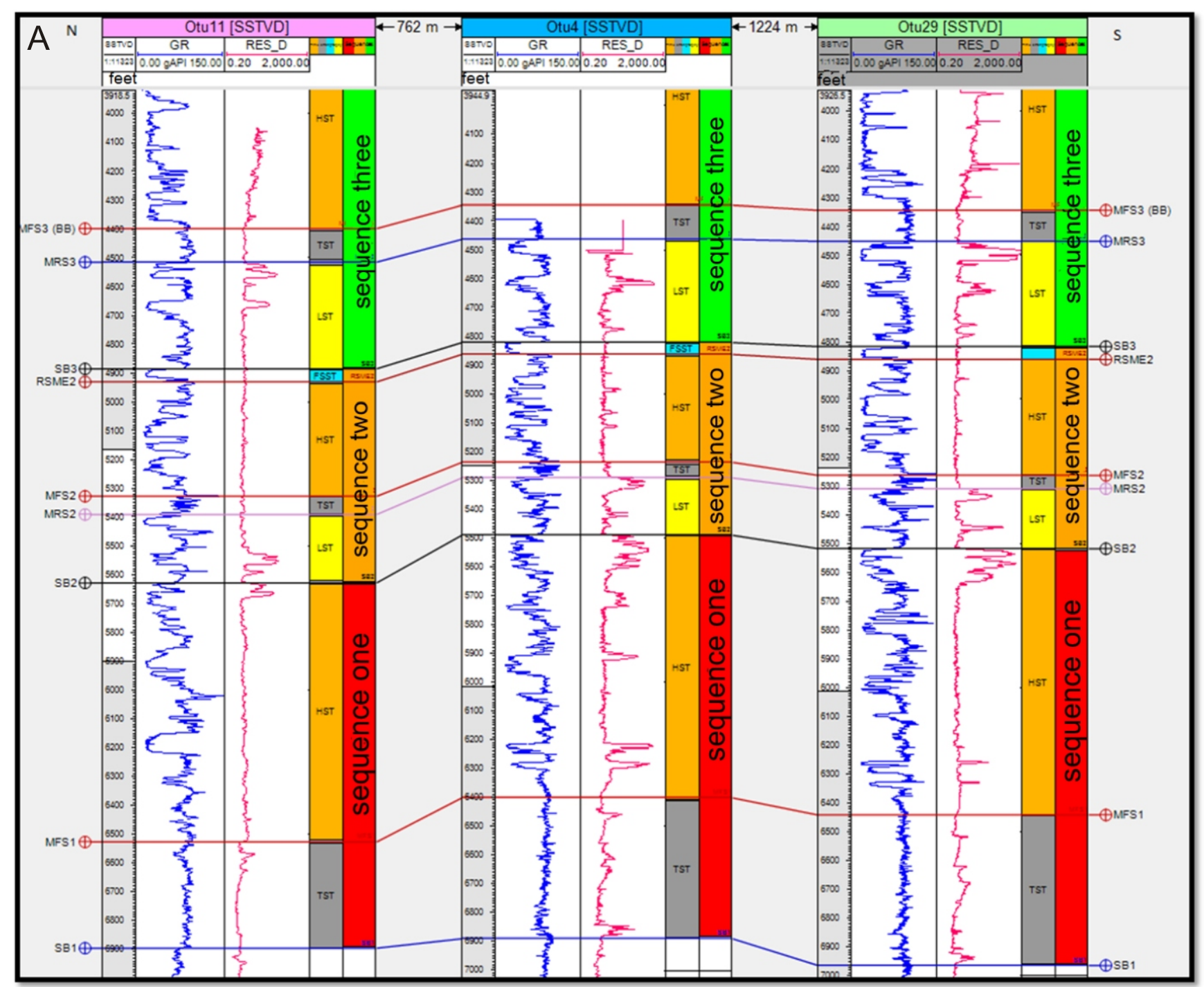

Fig. 8. Correlation log panels for boreholes 11, 4 and 29 (A)

A - the serrated log character is interpreted to represent a fluvial floodplain, while blocky patterns are interpreted to be fluvial channel while blocky patterns are interpreted to be fluvial channel deposits; HSTs are inferred to be prograding clinoforms; sequence two is

sion of fluvial valleys into the shelf. Prograding forced regressive deposits (FSST) are present. These fluvial channel sands have excellent reservoir qualities. The TSTs in the field capped the LST facies and consist of mainly marine shales. HSTs are made up of coarsening and shallowing upwards intervals having fluvial and deltaic sands near the top of the unit. HSTs are very thick in most of the boreholes studied in the Otu Field. This may be the result of high subsidence rates, high input of sediments and instability caused by underlying shale, as also observed in the Gulf Coast (Winker, 1982). The potential reservoirs in the Otu Field are mainly channel sands of LST and point bars of HST that show low and higher values of GR and resistivity, respectively (Fig. 19). 


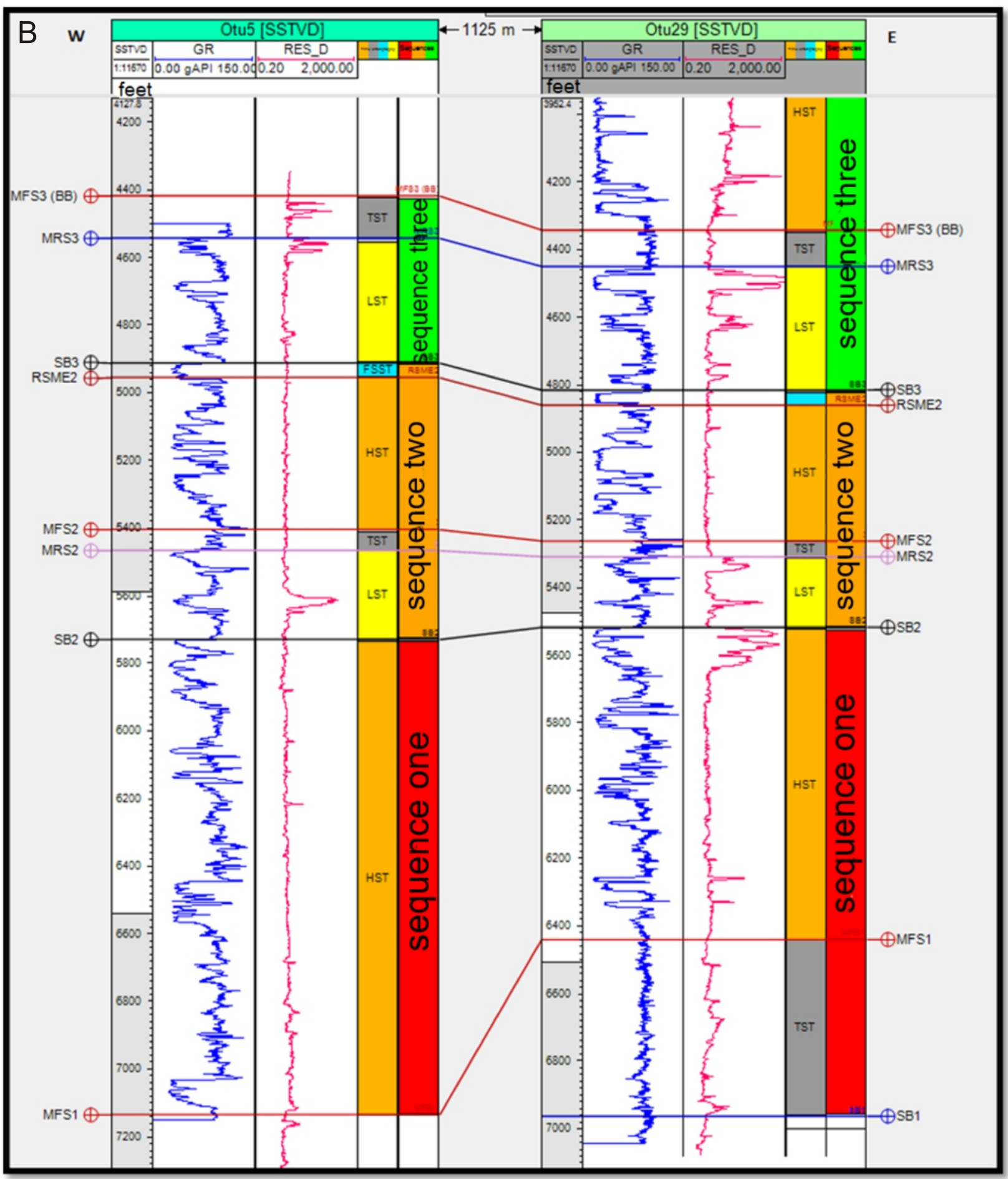

and 5 and 29 (B) indicating a coarsening upwards sequence

deposits, with bell-shaped deposits interpreted to be tidal channels; B - serrated log character are interpreted to be fluvial floodplain thicker at the eastern part of the field

As regards quality and geometry of reservoirs in the Otu Field, point bars of fluvial channels that are cut by sand-filled channels are the most important. The marine shales of the TST that were identified in the Otu Field would probably serve as the potential source rocks for the hydrocarbons found in the reservoirs of the Otu Field.
The results of lithostratigraphic correlation show some sand units occurring at greater depths than in adjacent units. These were interpreted to be a result of syndepositional faulting in the Otu Field. These faults probably serve as the major traps for the accumulation of hydrocarbons. However, the shales of the TST and those of HST could both provide seals for hydrocarbons in 


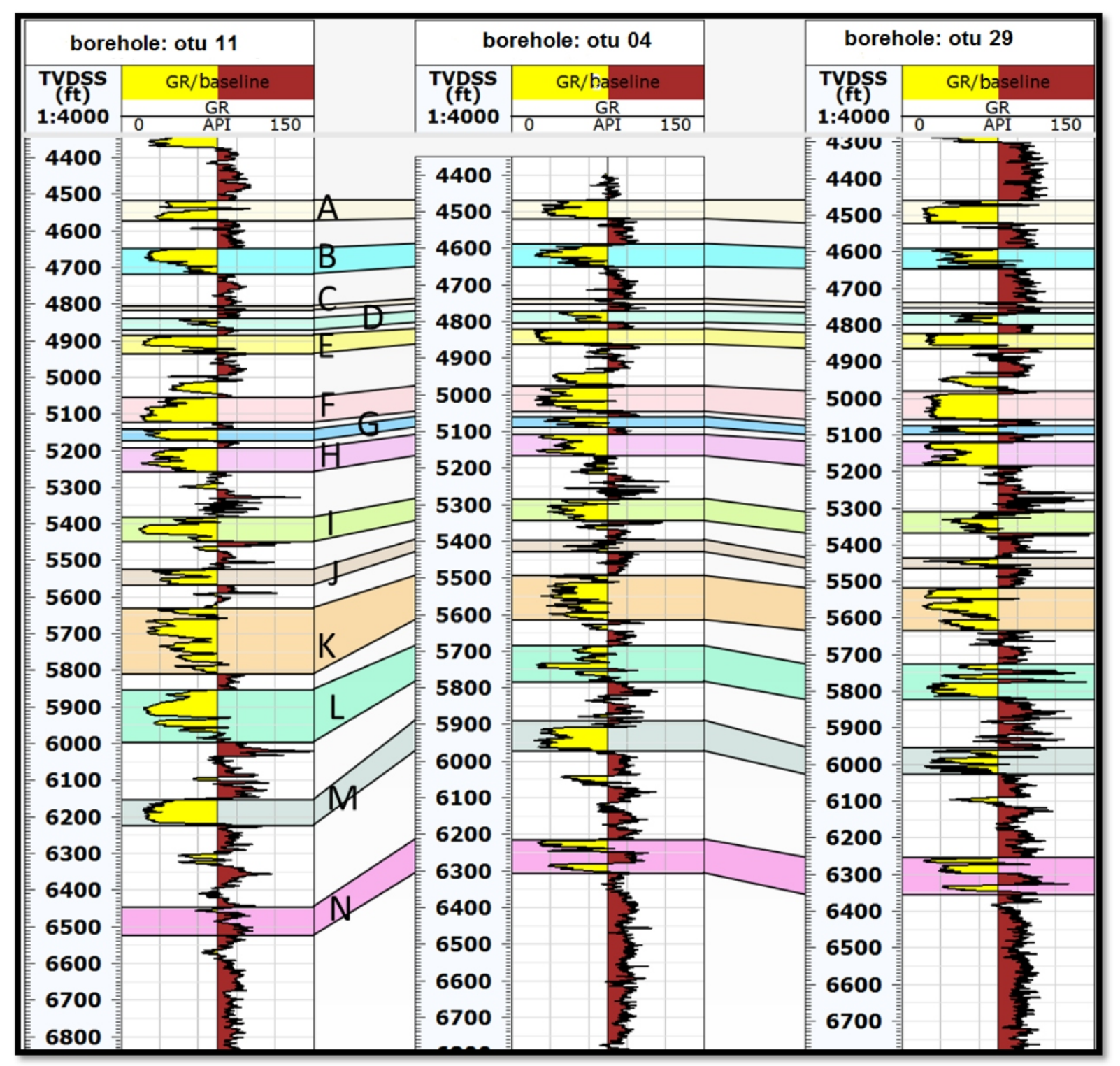

Fig. 9. Representative lithostratigraphic correlation of three boreholes in the Otu Field showing fourteen reservoir sands

the reservoir sands within Otu Field. Therefore, the reservoir rocks of the LST and HST and seals from marine shale of the TST and HST could combine to form stratigraphic traps for hydrocarbon accumulation.

\section{CONCLUSIONS}

The Agbada Formation of the Niger Delta is characterized by stratigraphic features which control the trapping of hydrocarbons within its deposits. The subsurface facies of the Otu Field is subdivided into three sequences. Sequence one is the deepest sequence subdivided into LST 1, TST 2 and HST 3 and consists predominantly of deposits of the transitional environment. The overlying sequence two consists of LST 2 (LPW), TST 2, HST 2 and FSST 2 and its depositional environment was predominantly shallow marine. Sequence three is the shallowest sequence stretching from the Agbada Formation into the Benin Formation, and consists of LST 3 (LPW), TST 3, and HST 3 laid down in transitional to shallow marine environments.

The seismic geomorphological study carried out on sequence boundaries and MFS 3 reveals a link between the depositional environment, type of channel and direction of palaeoflow relative to the faults. Channel belts are associated with continental to transitional depositional environments, while individual relatively shallow and less sinuous channels were as- 


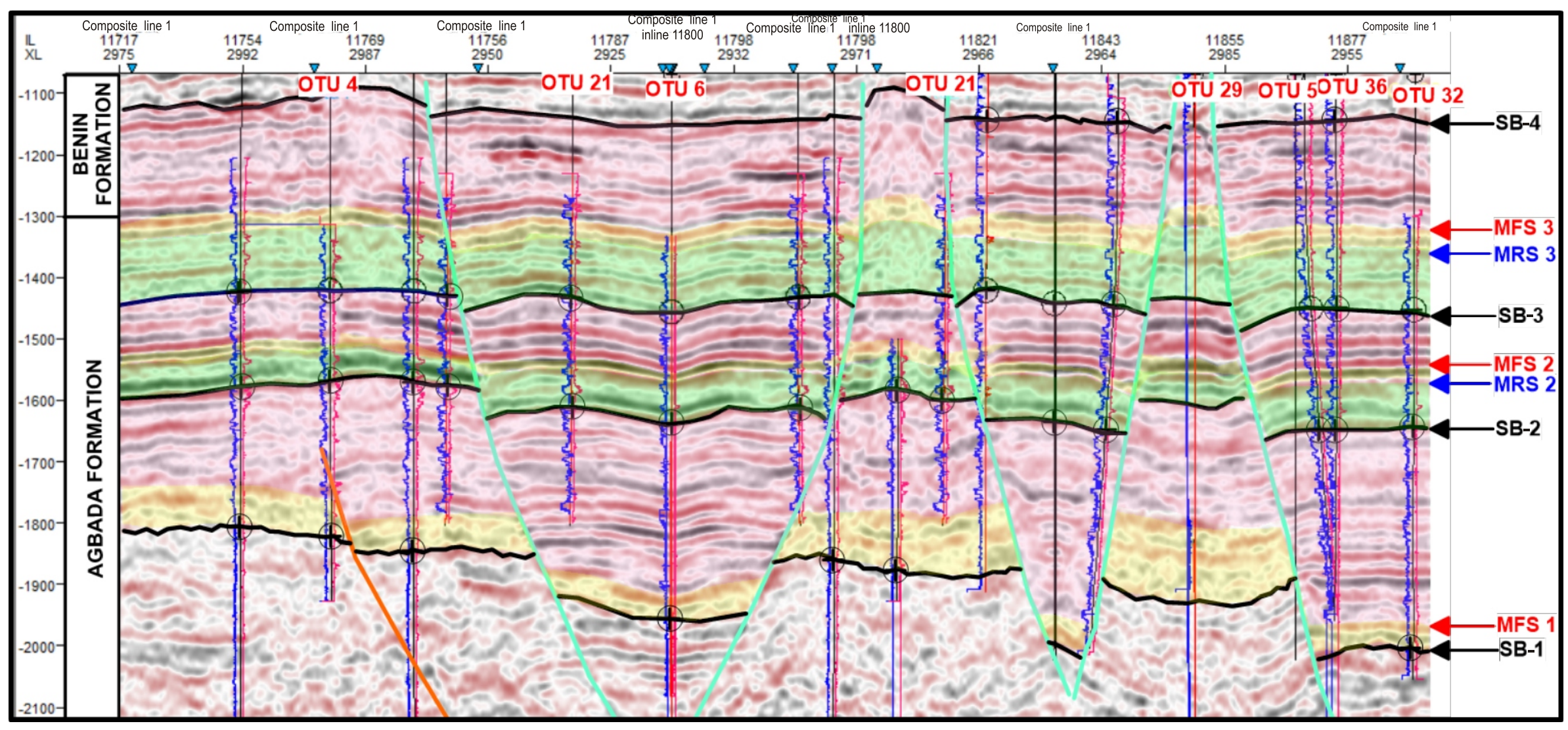

Fig. 10. Sequence stratigraphy architecture with the horst and graben structure within the Otu Field, showing sequence boundaries and stratigraphic surfaces mapped 


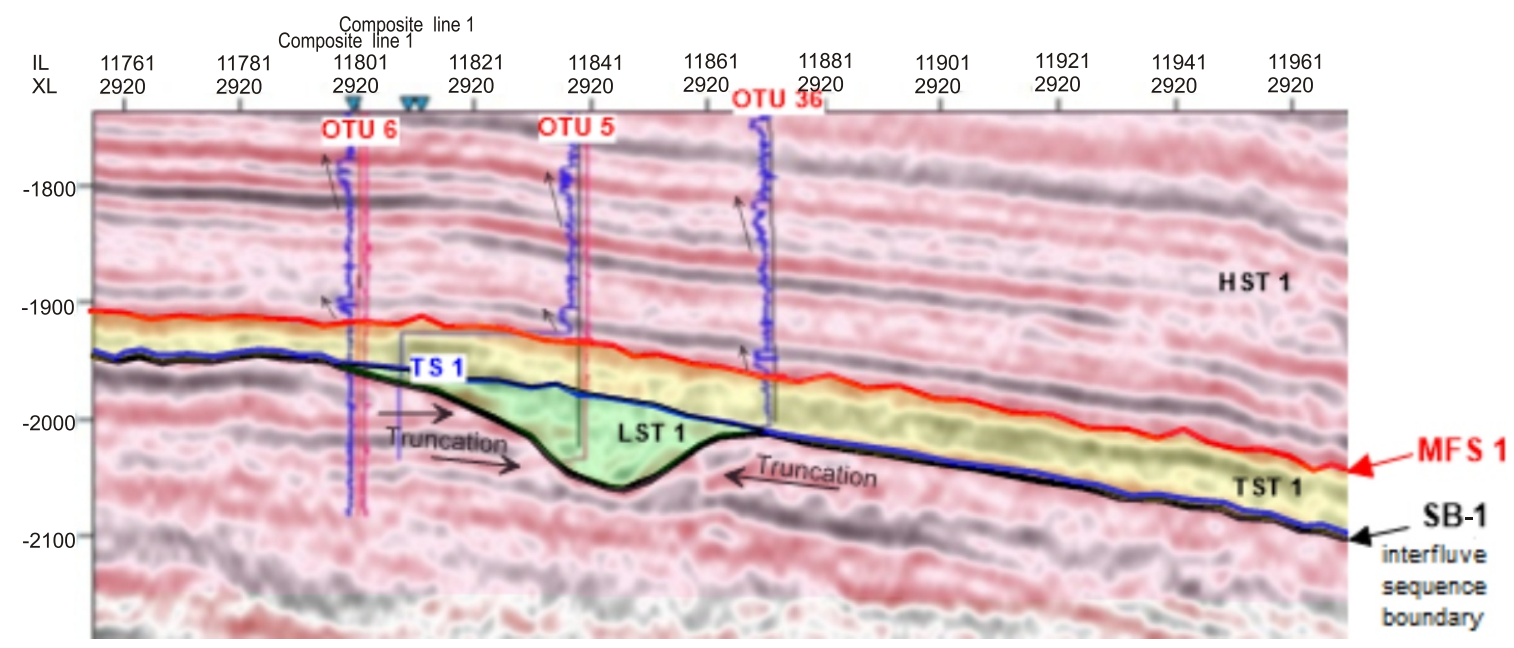

Fig. 11. Sequence boundary one identified on seismic sections revealing interfluve sequence boundary SB-1

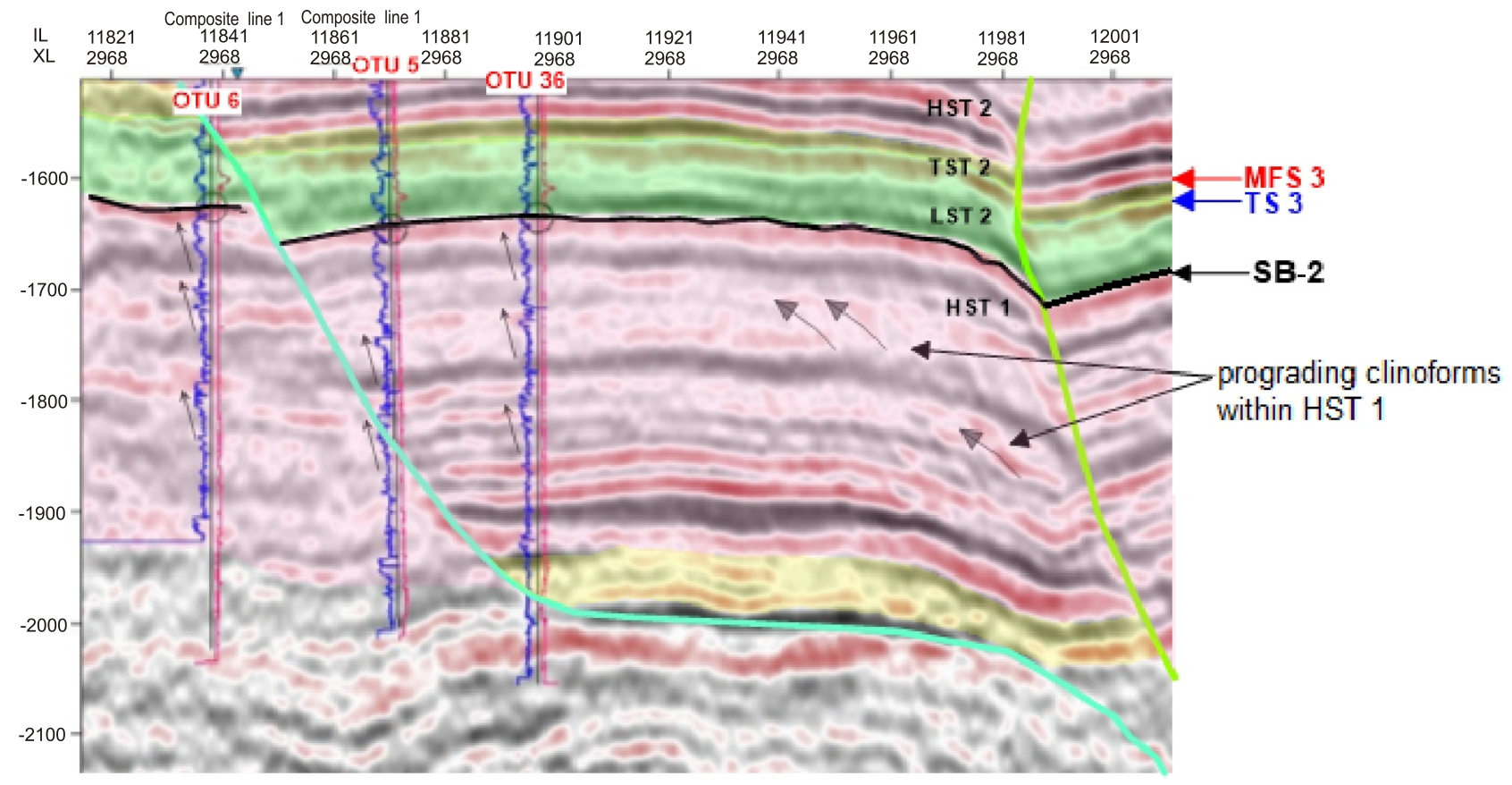

Fig. 12. Sequence boundary two identified on seismic sections showing prograding clinoforms within HST 1

sociated with shallow marine deposits. Channel belts are oriented perpendicular to faults, while individual channels (incised valley) were parallel and rarely affected by the faults.

This integrated study therefore reveals insights into the effects of tectonic events as they significantly affect the relationship between structural features such as faults and stratigraphic features such as channels within the field, therefore providing a profitable means to guide hydrocarbon exploration and production strategies.

On the basis of reservoir quality in the Otu Field, point bars of fluvial channels that are cut by sand-filled channels are the most important. The reservoir rocks of the LST and HST and seals from marine shale of the TST and HST could together form stratigraphic traps for hydrocarbon accumulation in the 


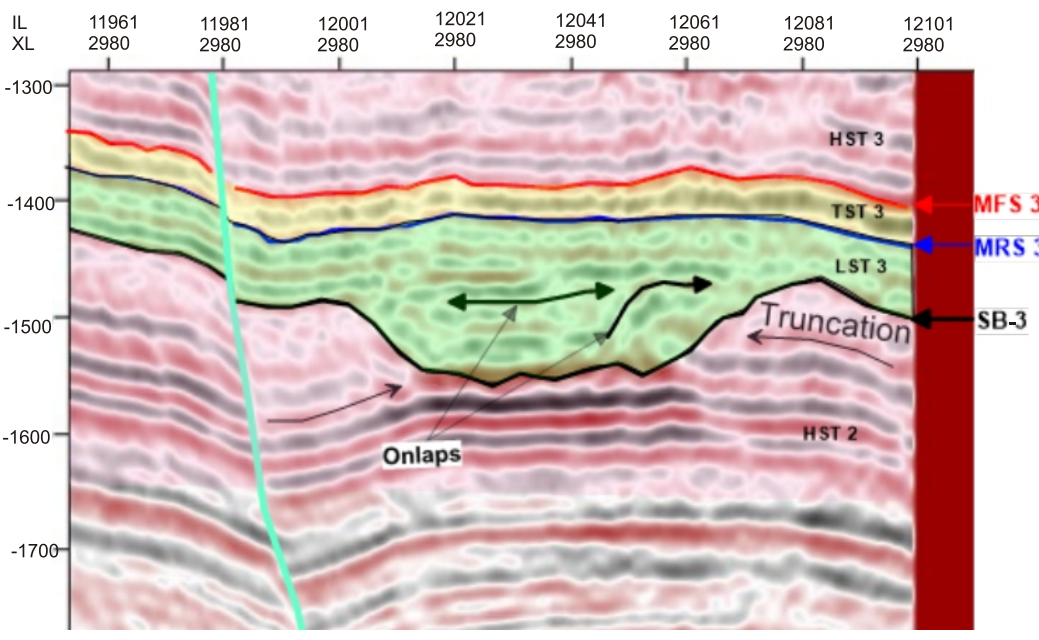

Fig. 13. Sequence boundary three identified on seismic sections

LST 3 has a complex geometry and its deposits should be widespread and not localized because TS 3 does not merge with SB-3

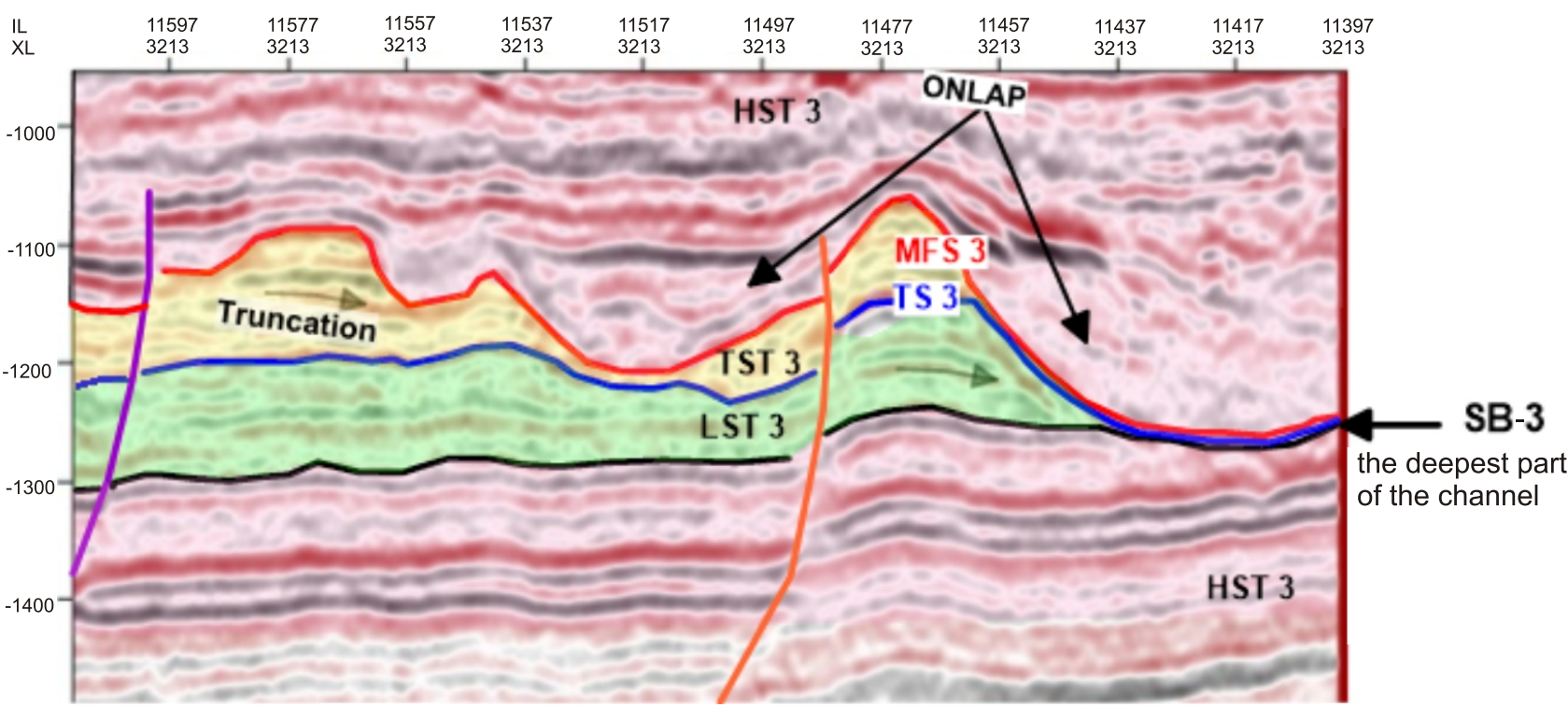

Fig. 14. Maximum flooding surface three (MFS 3)

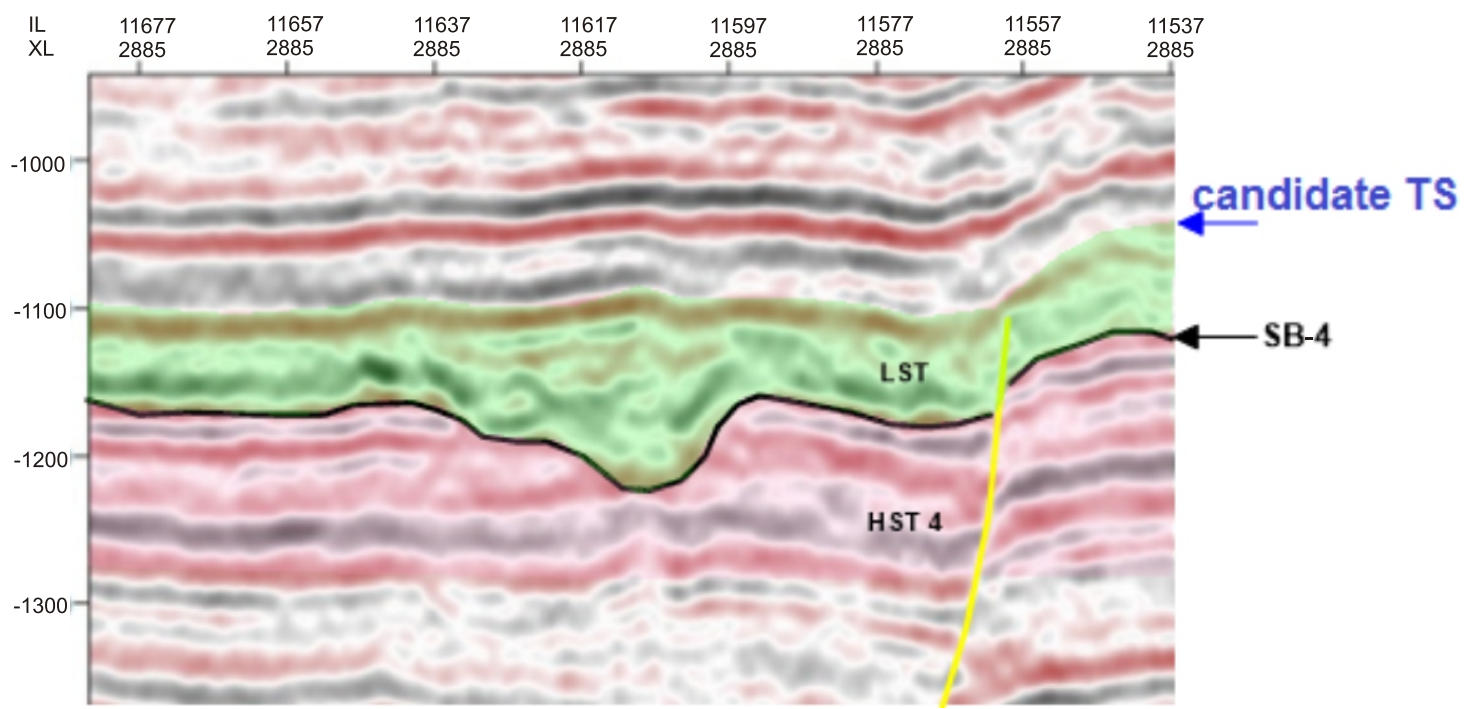

Fig. 15. Sequence boundary four

SB-4 separates the underlying sequence three from the overlying sequences 
Relationship between systems tracts, reservoirs and their respective depositional environments

\begin{tabular}{|c|c|c|c|c|}
\hline Sequence & Systems tracts & Reservoirs & Depositional environment per sequence & Formation \\
\hline \multirow{3}{*}{ III } & HST 3 & & $\begin{array}{l}\text { transitional } \\
\text { to continental }\end{array}$ & Benin \\
\hline & TST 3 & & \multirow{2}{*}{ shallow marine } & \multirow{9}{*}{ Agbada } \\
\hline & LST 3 (LPW) & $\mathrm{A}, \mathrm{B}, \mathrm{C}$ and $\mathrm{D}$ & & \\
\hline \multirow{4}{*}{ II } & FSST 2 (sharp based) & $\mathrm{E}$ & \multirow{4}{*}{ shallow marine } & \\
\hline & HST 2 & $\mathrm{~F}, \mathrm{G}$ and $\mathrm{H}$ & & \\
\hline & TST 2 & & & \\
\hline & LST 2 (LPW) & $\mathrm{I}$ and $\mathrm{J}$ & & \\
\hline \multirow{3}{*}{ I } & HST 1 & $\mathrm{~K}, \mathrm{~L}, \mathrm{M}$ and $\mathrm{N}$ & \multirow{3}{*}{ transitional } & \\
\hline & TST 1 & & & \\
\hline & $\begin{array}{c}\text { LST } 1 \text { lowstand } \\
\text { Fan (LF) - point bar deposits }\end{array}$ & & & \\
\hline
\end{tabular}

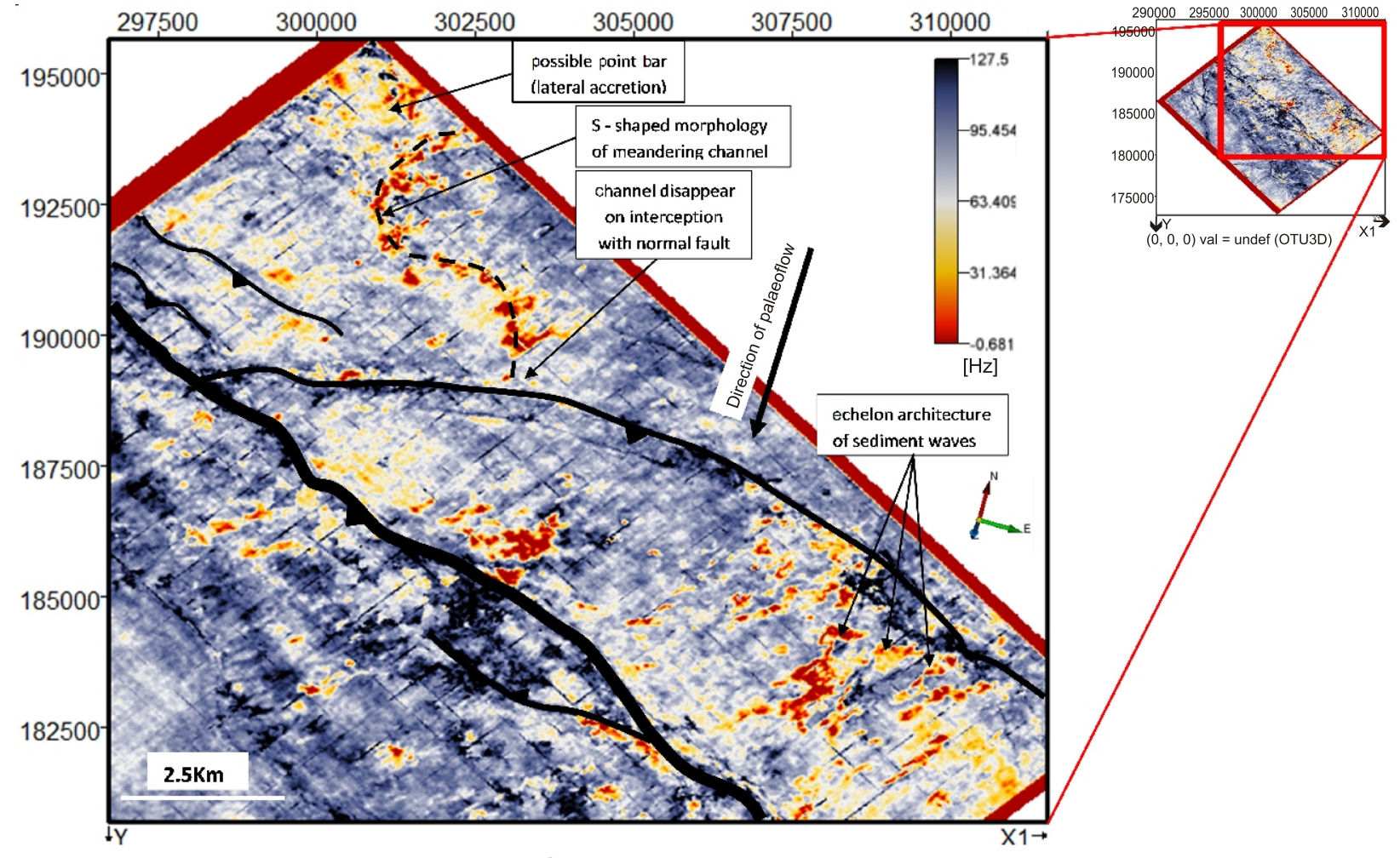

Fig. 16. Spectral decomposition stratal slice

A point bar was observed here and the channel disappears on interception with normal faults; the colour code represents the frequency 


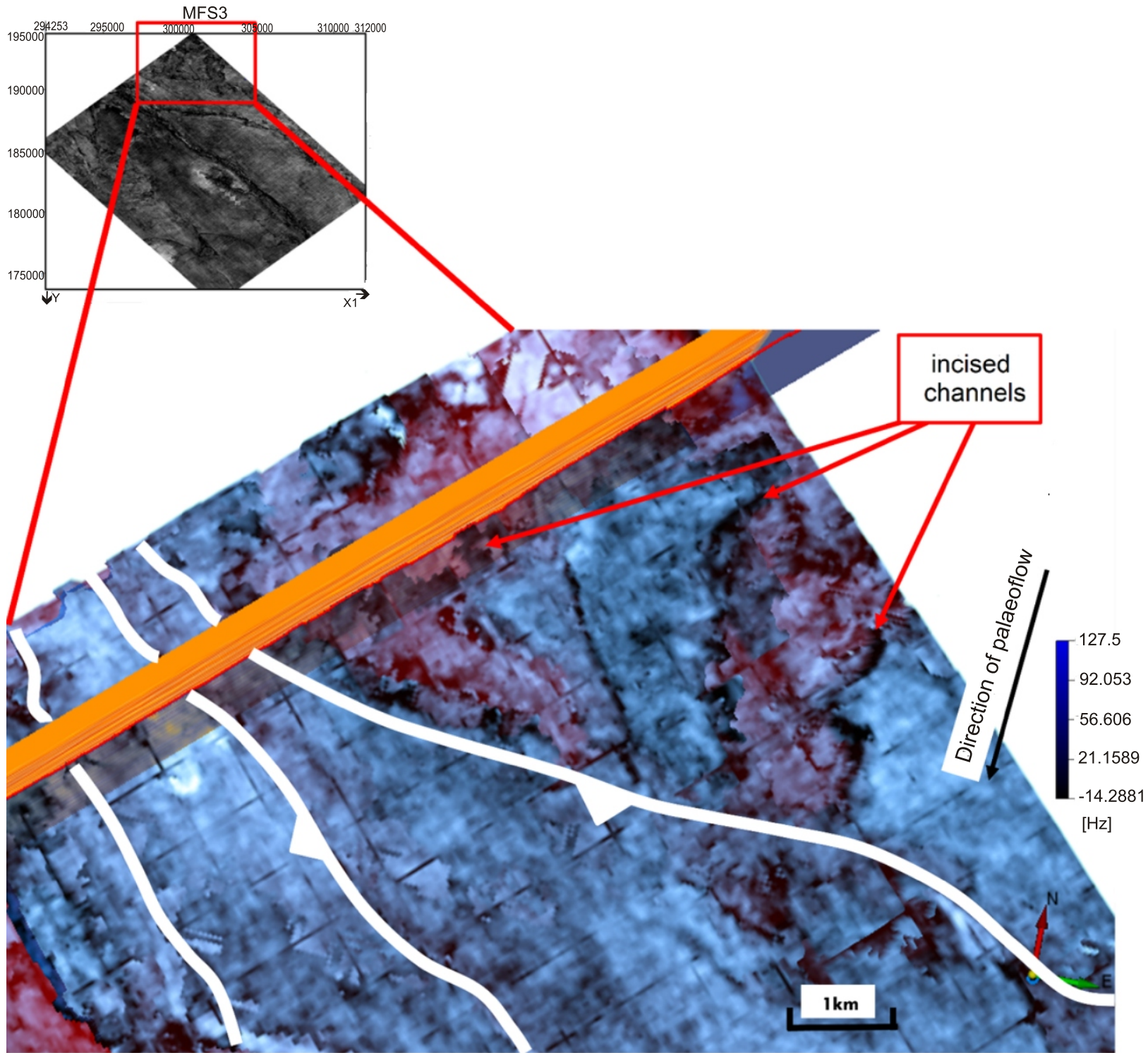

Fig. 17. Spectral decomposition at (10 and $40 \mathrm{~Hz}$ ) on the MFS 3 stratal slice showing the channel NE-SW direction (+30 and $-30 \mathrm{~ms})$

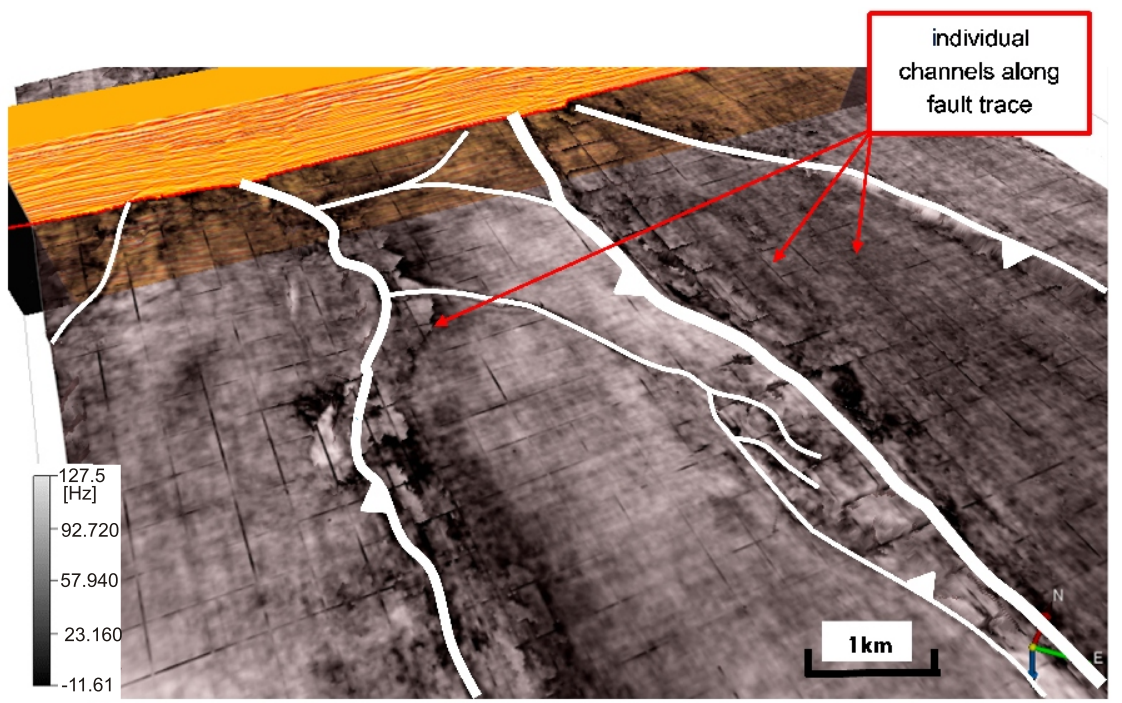

Fig. 18. Similarity (coherency) on the SB-2 stratal slice (+30 and $-30 \mathrm{~ms})$

The individual channel observed on SB-2 is subtle and directed along the hanging wall of the fault 


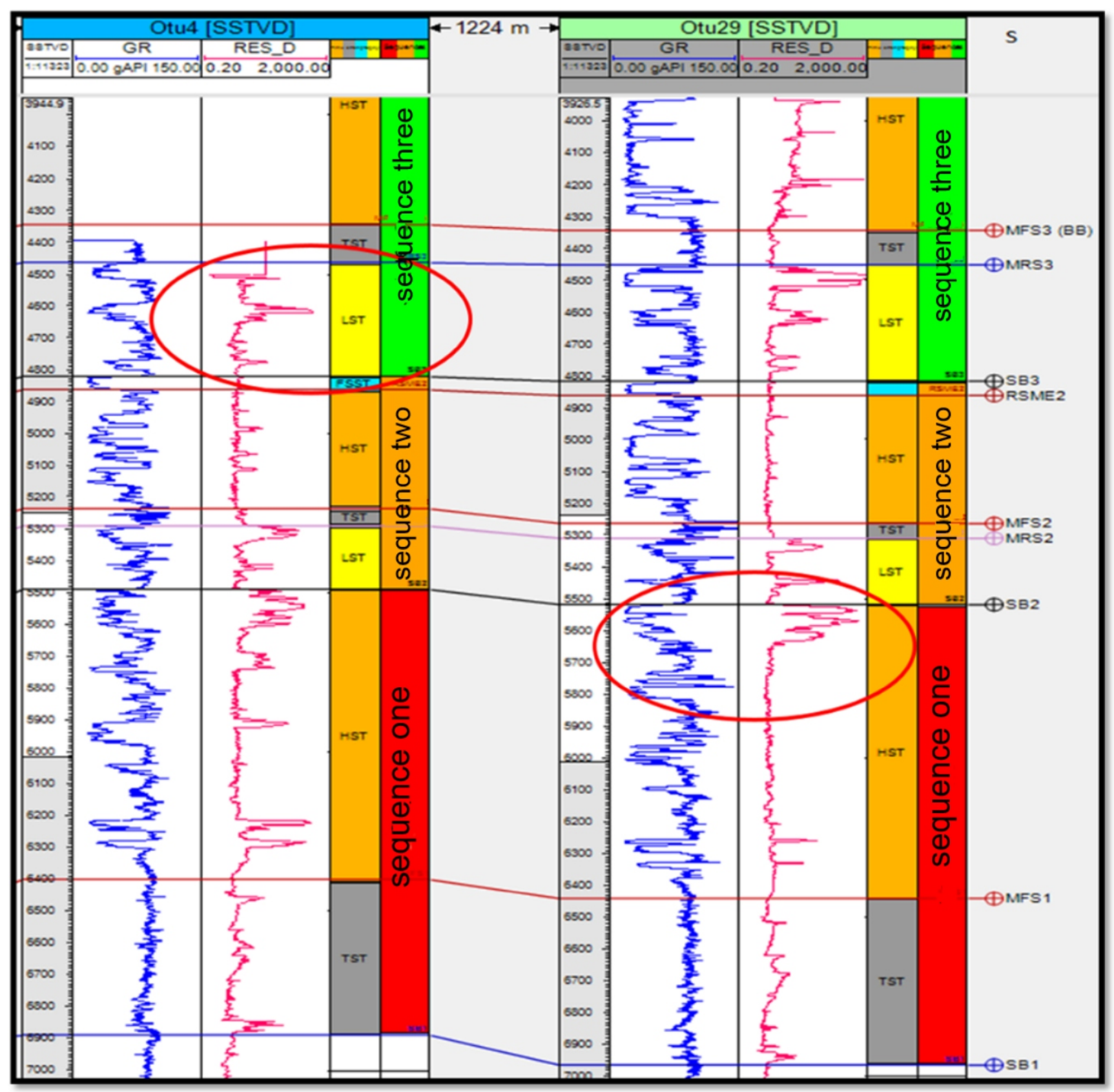

Fig. 19. Low gamma ray and high resistivity values of potential reservoirs in the Otu Field

Otu Field. Additional data such as biostratigraphic, core and permeability data are needed to integrate the results in order to establish more reliable interpretations in the field.

Acknowledgements. We thank Shell Petroleum Development Company (SPDC) Nigeria for the provision of the data. We gratefully acknowledge the invaluable support given to us by King Fahd University of Petroleum and Minerals, Dhahran, Saudi Arabia. Constructive review comments from G. Korvin and M. Kaminski are appreciated. We also thank O. Odumade and F. Oluwabamiwa for their technical advice. The Editor-in-Chief T.M. Peryt, reviewer J. Ogala and, in particular, an anonymous reviewer are acknowledged for their constructive comments. 


\section{REFERENCES}

Amigun, J.O., Adewoye, O., Olowolafe, T., Okwoli, E., 2014. Well logs-3D seismic sequence stratigraphy evaluation of "holu" field, Niger Delta, Nigeria. International Journal of Science and Technology, 4: 26-36.

Beka, F., Oti, M., 1995. The distal offshore Niger Delta: frontier prospects of a mature petroleum province. In: Geology of Deltas (eds. M.N. Oti and G. Postma): 237-241. A.A Balkema, Rotterdam.

Bustin, R., 1988. Sedimentology and characteristics of dispersed organic matter in Tertiary Niger Delta: origin of source rocks in a deltaic environment. AAPG Bulletin, 72: 277-298.

Catuneanu, O., 2002. Sequence stratigraphy of clastic systems: concepts, merits, and pitfalls. Journal of African Earth Sciences, 35: 1-43.

Catuneanu, O., Galloway, W.E., Kendall, C.G.St.C., Miall, A.D., Posamentier, H.W., Strasser, A., Tucker, M.E., 2011. Sequence stratigraphy: methodology and nomenclature. Newsletters on Stratigraphy, 44: 173-245.

Christie-Blick, N., 1991. Onlap, offlap, and the origin of unconformity-bounded depositional sequences. Marine Geology, 97: $35-56$.

Corredor, F., Shaw, J.H., Bilotti, F., 2005. Structural styles in the deep-water fold and thrust belts of the Niger Delta. AAPG Bulletin, 89: 753-780.

Doust, H., Omatsola, M., 1990. Petroleum geology of the Niger Delta. Geological Society Special Publications, 50: 365-365.

Ejedawe, J., 1986. The expulsion criterion in the evaluation of the petroleum source beds of the tertiary Niger Delta. Journal of Petroleum Geology, 9: 439-450.

Evamy, B., Haremboure, J., Kamerling, P., Knaap, W., Molloy, F., Rowlands, P., 1978. Hydrocarbon habitat of Tertiary Niger delta. AAPG Bulletin, 62: 1-39.

Fagbenro, A.W., Woma, T.Y., 2013. A seismic analysis of structural history of Makad Field, onshore Niger Delta and its implications for petroleum occurrence. International Journal of Science and Research, 2: 127-131.

Futalan, K., Mitchell, A., Amos, K., Backe, G., 2012. Seismic facies analysis and structural interpretation of the Sandakan sub-basin, Sulu Sea, Philippines. AAPG International Conference and Exhibition (Singapore), www.searchanddiscovery.com/pd fz/documents/2012/30254futalan/ndx_futalan.pdf.html.

Helland-Hansen, W., Gjelberg, J.G., 1994. Conceptual basis and variability in sequence stratigraphy: a different perspective. Sedimentary Geology, 92: 31-52.
Hunt, D., Tucker, M.E., 1992. Stranded parasequences and the forced regressive wedge systems tract: deposition during base-level fall. Sedimentary Geology, 81: 1-9.

Hunt, D., Tucker, M.E., 1995. Stranded parasequences and the forced regressive wedge systems tract: deposition during base-level fall-reply. Sedimentary Geology, 95: 147-160.

Lehner, P., De Ruiter, P., 1977. Structural history of Atlantic margin of Africa. AAPG Bulletin, 61: 961-981.

Nton, M., Adesina, A., 2009. Aspects of structures and depositional environment of sand bodies within tomboy field, offshore western Niger Delta, Nigeria. RMZ - Materials and Geoenvironment, 56: 284-303.

Nwachukwu, J.I., Chukwura, P.I., 1986. Organic matter of Agbada formation, Niger Delta, Nigeria. AAPG Bulletin, 70: 48-55.

Onayemi, J., Oladele, S., 2014. Analysis of facies and depositional systems of "Ray" field, onshore Niger Delta basin, Nigeria. SEG Annual Meeting, www.onepetro.org/conference-paper/SEG$-2014-0019$

Oyedele, K., Ogagarue, D., Mohammed, D., 2013. Integration of 3D seismic and well log data in the optimal reservoir characterization of "Emi" field, offshore Niger delta oil province, Nigeria. American Journal of Scientific and Industrial Research, 4: 11-21.

Posamentier, H.W., Davies, R.J., Cartwright, J.A., Wood, L., 2007. Seismic geomorphology - an overview: applications to hydrocarbon exploration and production. Geological Society Special Publications, 277: 1-14.

Reijers, T., 2011. Stratigraphy and sedimentology of the Niger Delta. Geologos, 17: 133-162.

Short, K., Stauble, A., 1967. Outline of geology of Niger Delta. AAPG Bulletin, 51: 761-779.

Stacher, P., 1995. Present understanding of the Niger Delta hydrocarbon habitat. In: Geology of Deltas (eds. M.N. Oti and G. Postma): 257-267. A.A. Balkema, Rotterdam.

Vail, P.R., 1987. Seismic stratigraphy interpretation procedure. AAPG Studies in Geology, 27: 1-10.

Van Wagoner, J.C., Mitchum, R.M., Campion, K.M., Rahmanian, V.D., 1990. Siliciclastic sequence stratigraphy in well logs, cores and outcrops. AAPG Methods in Exploration Series, 7.

Whiteman, A.J., 1982. Nigeria, its Petroleum, Geology, Resources and Potential, v. I and II, Edinburgh, Graham and Trotman.

Winker, C.D., 1982. Cenozoic shelf margins, northwestern Gulf of Mexico. Gulf Coast Association of Geological Societies Transactions, 32: 427-448. 